\title{
MJN CROSS SECTIONAL STUDY ON KNOWLEDGE AND PRACTICES AMONG INDIAN NURSES ABOUT COVID 19
}

\author{
Jyoti $^{*}$, Khina Sharma \\ College of Nursing, Govt Medical College and Hospital, India \\ *Corresponding Author’s_Email: jyoti_kath@rediffmail.com
}

\begin{abstract}
Background - COVID 19 pandemic has caused health concern all over the world, therefore it is the need of the hour that every individual should be equipped with knowledge related to the disease. In this study, knowledge and practices were assessed among the nurses. As India is one of the leading country suffering from this pandemic spread where local transmission is reported and due to this author thought of carrying out the study. Purpose - of the study was to identify the knowledge and practices of nurses, in order to assess the readiness of nurses for upcoming challenges. Methods- An online sample of Indian Nurses was successfully recruited via author's networks. A self-structured online questionnaire was completed by participants. The questionnaire consisted of 30 items in two parts related to knowledge and practice assessment associated with COVID-19. Results - Among 720 participants, good knowledge was observed in 50.6\% participants and excellent knowledge (36.4\%) was revealed related to myths and facts about COVID 19 among participants. Moreover, the practices proved to be excellent among $83.1 \%$. Moderate linear positive correlation was found between knowledge and practices therefore inference was drawn that knowledge and practices were interdependent. Association between knowledge and practice scores with age gender and education was found to be significant which proves that knowledge and practices were influenced by these variables. Moreover, no literature is available till date related to knowledge and practices of Indian nursing personnel related to COVID-19. Conclusion - The study revealed that that nurses have good knowledge, practices and the care of COVID-19 patients in India is in safe hands. Moreover, the frontline nursing fraternity is all set to win the battle against COIVD-19 in near future. The study also acts as a tool to bring awareness among the participants, as the right answers were shared after responses submission.
\end{abstract}

Keyword-COVID19, Knowledge, Practices, Nurses, India

\section{INTRODUCTION}

According to WHO, SARS coronavirus (SARS$\mathrm{CoV}$ ) was identified in 2003, thought to be animal virus and claimed to infect 26 countries. Later in 2012, Middle East Respiratory Syndrome Corona Virus (MERS-CoV) another virus transmitted between animal and humans was identified. The latest introduction of novel corona virus too has proved to be a spill over virus from animals and on $4^{\text {th }}$ April 2020 total $1,130,664$ cases has been reported, deaths reported were 60,147 (Surveillances, 2020; WHO, 2019; WHO, 2020a; Who.int., 2020b).

In December 2019 number of pneumonia cases was reported in Wuhan, China. Scientists found that the cases were caused by $\beta$-coronavirus. Till 2020, it was known as novel corona Virus $(2019-\mathrm{nCoV})$, later on $12^{\text {th }}$ January 2020 WHO officially named it as coronavirus disease 2019 (COVID -19) and Coronavirus Study Group (CSG) an international Committee proposed name as SARS -CoV-2 on $11^{\text {th }}$ February 2020. COVID19 has been declared as a pandemic by WHO (World Health Organization) on $30^{\text {th }}$ January 2020 and is health concern at international level (Guo et al., 2020).

According to Zhou et al., (2020), based on genome sequencing and analysis it has been suspected that natural host of virus is bat and SARS-CoV-2 is transmitted from bats to humans, though the intermediate host is not known. 


\section{Transmission}

The virus is highly contagious and it is spreading worldwide. Human to human transmission of SARSCoV-2 occurs mainly through the droplet transmission, respiratory secretions and contact transmission (Guan et al. 2020). Based on data available the incubation time of COVID-19 is generally within 2 to 14 days (Li et al., 2020).

\section{Clinical characteristics}

The symptoms among infected patients are fever, cough, myalgia or fatigue; less common symptoms are sputum production, headache, haemoptysis, diarrhoea. Dyspnoea develops on $8^{\text {th }}$ days after onset of illness and lymphopenia. Reported complications include acute respiratory distress syndrome, acute cardiac injury and secondary infection. Literature also report that comorbidities contribute to development of complication and mortality (Huang et al., 2020).

\section{Prevention}

Prevention and control methods are suggested at three levels - National, Case related population and general population level

Guidelines are suggested by WHO in order to prepare for the pandemic, its spread control, safety measure related to prevention and case management of COVID-19. It also aims at bringing awareness among the general population for the prevention and care, case isolation identification and follow-up of contacts, environmental disinfection and use of personal protective equipment.

\section{Treatment}

Till date no antiviral treatment has been confirmed against COVID-19. However, the symptomatic treatment and supportive care is suggested (Adhikari et al., 2020).

\section{Objectives of the study were to:}

1. Assess the knowledge and practices related to COVID -19 .

2. Identify the correlation between knowledge and practices

3. Find out association between score of Knowledge and practice with demographic variables.

\section{METHODOLOGY}

This study involved survey from $23^{\text {rd }}$ March 2020 to the week when lockdown occurred in India. As it was not feasible to choose community-based sampling survey, therefore it was decided to collect data using the internet. Social media and author's network were used for collection of the data. Initial introduction included the objective of the study and correct responses were shared after participation in order to bring awareness about COVID 19. The respondents were not restricted to any geographical area as online platform was used for data collection. The participation was completely voluntary based.

Participants had to answer multiple choice questions and had to confirm their willingness to be voluntary. After giving consent, participants were directed to a self-report questionnaire.

\section{Measures}

The questionnaire consisted two parts: Demographics and knowledge and practice questionnaire related to COVID19.

Demographic variables included-age, gender, education, occupation, residential area.

Questionnaire had 30 questions in two parts related to knowledge and practice assessment. Knowledge was assessed in three sections and practices were assessed especially related to hand washing and use of mask.

Part A-Assessment of Knowledge related to COVID19

Section A-COVID 19 causes and clinical manifestations

Section B-Diagnosis of COVID 19

Section C-Myths and Facts related to COVID 19

Part B - Assessment of Practices especially related hand washing and mask use.

Total 895 participants responded the survey, as selfreporting method, that too using online method was adopted; due to this few participants did not complete the survey. Final sample consisted of 720 participants who completely responded to all the questions.

\section{RESULTS}

\section{Sociodemographic Profile of Participants}

Among this final sample, the average age was 25 years (standard deviation (S.D) \pm 5.72 , range 18-55) and 589 were females $(81.8 \%)$.

Education - majority were nursing students 
304(42.2\%), followed by Bachelor degree holders (B.Sc Nursing) 248(34.5\%), post graduate nursing personnel were 114(34.5\%).

Occupation - 266 (36.9\%) were staff nurse who worked at bedside whereas 304(42.2\%) were future nursing personnel i.e, nursing students, rest $120(16.74 \%)$ were nursing teachers/faculty.

Experience - Majority of the samples had experience less than five years with mean of 2.52 (S.D \pm 4.32$)$. It was also observed that currently $30(4.16 \%)$ participants were not working and participants who had more than 15yeras of experience were $29(4.02 \%)$. The mean experience observed among participants was 2.52 years with $\mathrm{S} . \mathrm{D} \pm 04.32$.

Northern part of India participated more in the survey as the data revealed that 421 (58.4\%) participants were from Punjab, Himachal and Chandigarh.

The samples who had known person in their social circle, who were exposed to COVID-19 were 70 (9.7\%) and they were neighbours $43(5.9 \%)$. (Table 1 ).

Table 1: Sociodemographic Profile of Participants

\begin{tabular}{|c|c|c|}
\hline Variable & $\begin{array}{l}\text { Frequency } \\
\text { (f) }\end{array}$ & Percentage (\%) \\
\hline \multicolumn{3}{|l|}{ Age (in years) } \\
\hline$\leq 20$ & 156 & 21.7 \\
\hline $21-30$ & 474 & 65.8 \\
\hline \multirow[t]{2}{*}{$>30$} & 90 & 12.5 \\
\hline & \multicolumn{2}{|c|}{$\begin{array}{c}\text { Mean } \pm \text { SD }(\text { Range })=24.96 \pm 5.72 \\
(18-55)\end{array}$} \\
\hline Gender & & \\
\hline Male & 131 & 18.2 \\
\hline Female & 589 & 81.8 \\
\hline \multicolumn{3}{|l|}{ Education } \\
\hline Student & 304 & 42.2 \\
\hline GNM & 44 & 06.1 \\
\hline B.Sc. Nursing & 248 & 34.5 \\
\hline M.Sc. Nursing & 114 & 15.8 \\
\hline $\mathrm{PhD}$ & 10 & 01.4 \\
\hline \multicolumn{3}{|l|}{ Occupation } \\
\hline Nursing Students & 304 & 42.2 \\
\hline Unemployed nurses & 30 & 4.16 \\
\hline Staff Nurses & 266 & 36.9 \\
\hline Nursing teachers & 120 & 16.74 \\
\hline \multicolumn{3}{|l|}{ Experience (in years) } \\
\hline & 309 & 42.9 \\
\hline$\leq 5$ years & 317 & 44 \\
\hline 6-10years & 57 & 07.9 \\
\hline 11-15years & 18 & 02.5 \\
\hline 16-20years & 11 & 01.6 \\
\hline \multirow[t]{2}{*}{ Above 20years } & 08 & 01.1 \\
\hline & \multicolumn{2}{|c|}{$\begin{array}{c}\text { Mean } \pm \text { SD (Range) }=02.52 \pm 04.32 \\
(0-34)\end{array}$} \\
\hline
\end{tabular}

\begin{tabular}{|l|c|c|}
\hline Residence & 153 & 21.3 \\
Chandigarh & 144 & 20.03 \\
Punjab & 126 & 17.5 \\
Himachal Pradesh & 89 & 12.4 \\
Haryana & 56 & 07.8 \\
Delhi & 45 & 06.2 \\
Rajasthan & 40 & 05.5 \\
Gujarat & 12 & 01.7 \\
Uttar Pradesh & 09 & 01.2 \\
Madhya Pradesh & 08 & 01.1 \\
Jammu \& Kashmir & 38 & 5.27 \\
Other States of India & & \\
& & \\
COVID-19 exposure in & & \\
social circle & 650 & 90.3 \\
No & 70 & 09.7 \\
Yes & \\
\hline
\end{tabular}

\section{Knowledge and Practices Related to COVID - 19}

Knowledge was assessed in three parts related to COVID-19 and overall knowledge about the disease was excellent among 92(12.8\%) participants and good knowledge scores were observed among 364 (50.6\%) participants, average knowledge was among 253 (35.1\%) and only 11 participants had below average knowledge (Table 2)(fig -1)

\section{Table 2: Overall Knowledge About Covid19}

\begin{tabular}{|l|l|c|c|}
\hline $\begin{array}{l}\text { Knowledge } \\
\text { about COVID-19 }\end{array}$ & Categories & $\begin{array}{c}\text { Frequency } \\
\text { (f) }\end{array}$ & $\begin{array}{c}\text { Percentage } \\
\text { (\%) }\end{array}$ \\
\hline \multirow{3}{*}{ (Maximum score= 46) } & Below average (0-11) & 11 & 01.5 \\
\cline { 2 - 4 } & Average (12-23) & 253 & 35.1 \\
\cline { 2 - 4 } & Good (24-34) & 364 & 50.6 \\
\cline { 2 - 4 } & Excellent (>35) & 92 & 12.8 \\
\cline { 2 - 4 }$N=720$ & \multicolumn{2}{|c|}{ Mean \pm SD (Range) $=26.19 \pm 7.33(5-44)$} \\
\hline \multirow{3}{*}{$N$}
\end{tabular}

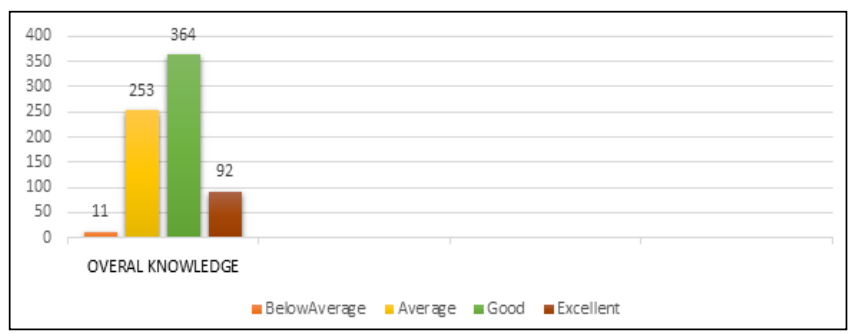

Figure 1: Overall Knowledge about COVID-19

\section{Section wise Knowledge About COVID-19}

Exploring further the details related to the knowledge it was found that $272(37.8 \%)$ participants had good knowledge regarding myths and facts about COVID-19 with mean score of 12.51 (S.D \pm 3.88 ) whereas in rest two areas i.e, COVID-19; causes and 
clinical manifestations and Diagnosis of COVID-19 score were average (Table 3)(fig 2).

Table 3: Sectionwise Knowledge About Covid-19

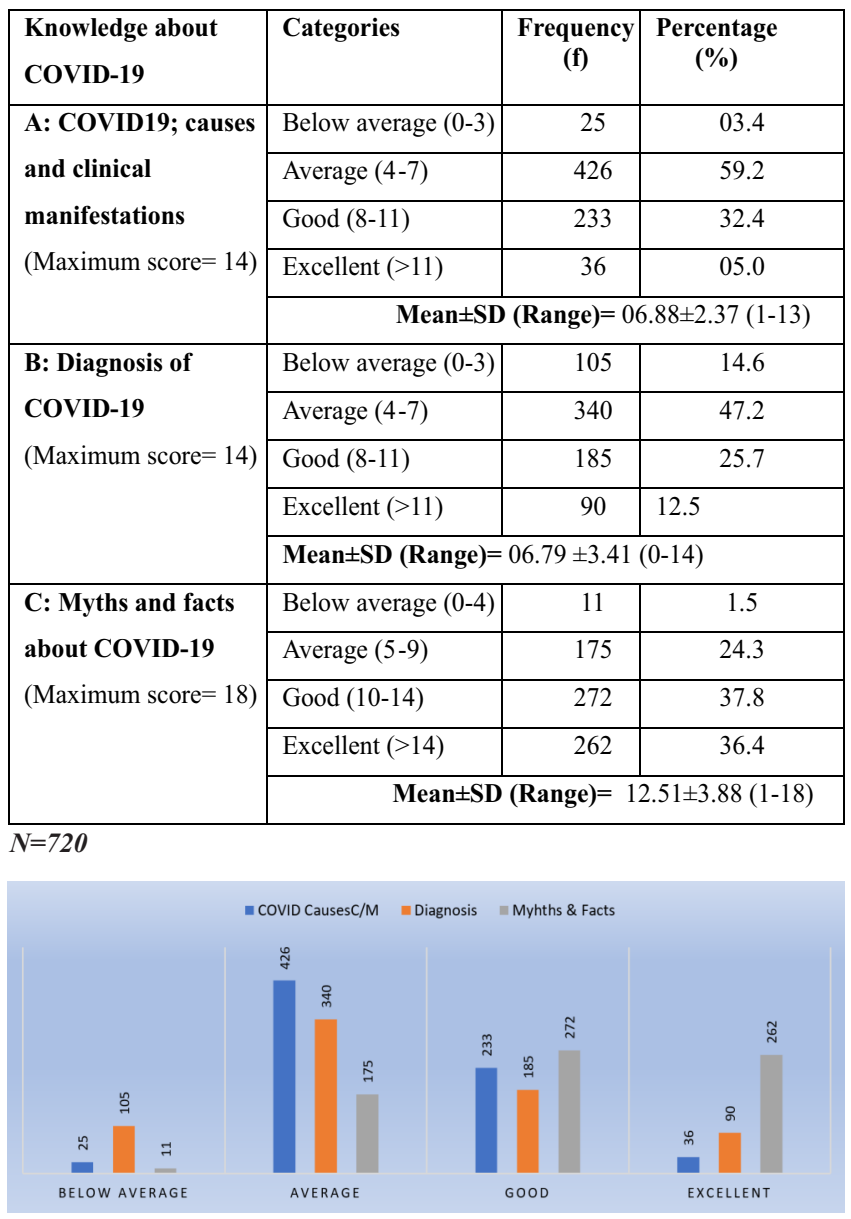

Figure 2: Section wise Knowledge about COVID-19

\section{Practices Related to COVID - 19}

Practice score revealed that majority of the participants had excellent 598 (83.1\%) practices related to COVID-19 prevention and management with mean score of 12.43 (S.D. \pm 2.37$)$. This could be because of the worldwide awareness created by national and international agencies, moreover the study participants were nursing professionals.

\section{Table 4: Practices about Covid19}

\begin{tabular}{|l|l|c|c|}
\hline $\begin{array}{l}\text { Practices related to } \\
\text { Mask use }\end{array}$ & Categories & $\begin{array}{c}\text { Frequency } \\
\text { (f) }\end{array}$ & $\begin{array}{c}\text { Percentage } \\
\text { (\%) }\end{array}$ \\
\hline \multirow{3}{*}{ Maximum score $=14)$} & Below average (0-3) & 14 & 1.9 \\
\cline { 2 - 4 } & Average (4-7) & 14 & 1.9 \\
\cline { 2 - 4 } & Good (8-11) & 94 & 13.1 \\
\cline { 2 - 4 } & Excellent (>11) & 598 & 83.1 \\
\cline { 2 - 4 } & \multicolumn{2}{|c|}{ Mean \pm SD (Range) $=12.43 \pm 2.37(0-14)$} \\
\hline
\end{tabular}

\section{Correlation between Knowledge and Practice}

In order to identify the correlation between knowledge and practice score the spearman coefficient correlation was used and it revealed that there was moderate linear positive correlation $(r=0.39)$. Hence it was proven that knowledge and practices were interdependent.

\section{Table 5: Correlation Between Knowledge And Practice}

\begin{tabular}{|c|c|c|}
\hline Variable & Correlation Coefficient & $P$-value ${ }^{*}$ \\
\hline Overall Knowledge-practices & 0.39 & $<0.001$ \\
\hline
\end{tabular}

Association Between Knowledge Score and Practice with Demographic Variables

Association between knowledge and demographic variables was calculated with help of Chi Square and results revealed that there was statistically significant association between knowledge score with age and education at $p$ value $<0.05$ (Table 6).

Table 6: Association of Knowledge With Demographic Variable

\begin{tabular}{|c|c|c|c|c|}
\hline Variables & $\begin{array}{c}\text { Below } \\
\text { average } \\
\text { knowledge } \\
(0-11)\end{array}$ & $\begin{array}{c}\text { Average } \\
\text { knowledge } \\
(12-23)\end{array}$ & $\begin{array}{c}\text { Good } \\
\text { knowledge } \\
(24-34)\end{array}$ & $\begin{array}{l}\text { Chi square } \\
\text { (df) } P \text {-Value }\end{array}$ \\
\hline Age (in years) & & & & \\
\hline$\leq 20$ & 2 & 62 & 71 & $20.94(6)$ \\
\hline $21-30$ & 9 & 176 & 229 & 0.002 \\
\hline$>30$ & 00 & 15 & 60 & \\
\hline Gender & & & & 2.69 (3) 0.44 \\
\hline Male & 2 & 54 & 59 & \\
\hline Female & 9 & 199 & 305 & \\
\hline Education & & & & \\
\hline Student & 04 & 117 & 138 & $21.11(12)$ \\
\hline GNM & 01 & 18 & 20 & 0.04 \\
\hline B.Sc. Nursing & 06 & 87 & 129 & \\
\hline M.Sc. Nursing & 00 & 27 & 74 & \\
\hline $\mathrm{PhD}$ & 00 & 04 & 03 & \\
\hline
\end{tabular}

Similarly, association between practices and demographic variables was calculated it was found that there was statistically significant association of practice score with gender and education at $p$ value $<0.05$ (Table 7). 
Table 7: Association of Practices With Demographic Variables

\begin{tabular}{|l|c|c|c|c|c|}
\hline Variables & $\begin{array}{c}\text { Below } \\
\text { average } \\
\text { Practices } \\
\mathbf{( 0 - 3 )}\end{array}$ & $\begin{array}{c}\text { Average } \\
\text { Practices } \\
\mathbf{( 4 - 7 )}\end{array}$ & $\begin{array}{c}\text { Good } \\
\text { Practices } \\
\mathbf{( 8 - 1 1 )}\end{array}$ & $\begin{array}{c}\text { Excellent } \\
\text { Practices } \\
\text { (>11) }\end{array}$ & $\begin{array}{c}\text { Chi square } \\
\text { (df) } \boldsymbol{P} \text { - } \\
\text { Value }\end{array}$ \\
\hline Age (in years) & 03 & 02 & 21 & 130 & $04.25(6)$ \\
$\leq 20$ & 11 & 09 & 64 & 390 & 0.4 \\
$21-30$ & 00 & 03 & 09 & 78 & \\
$>30$ & 04 & 03 & 27 & 97 & $9.670(3)$ \\
\hline Gender & 10 & 11 & 67 & 501 & 0.02 \\
Male & 07 & 05 & 35 & 257 & $29.76(12)$ \\
Female & 00 & 04 & 12 & 28 & 0.003 \\
\hline Education & 06 & 02 & 32 & 208 & \\
Student & 01 & 02 & 15 & 96 & \\
GNM & 00 & 01 & 00 & 09 & \\
B.Sc. Nursing & 06 & & & & \\
M.Sc. Nursing & 01 & & & & \\
PhD & 00 & & & & \\
\hline
\end{tabular}

$N=720$

Hence inference was drawn that demographic variables like age, gender and education influenced the knowledge and practice of the participants about COVID19.

\section{DISCUSSION}

Present study was conducted during the early stages of COVID-19 outbreak in India. As from the view of infection prevention and control during COVID-19 outbreak, nurses must exhibit high knowledge and correct practices. This study aimed to find out the knowledge related to COVID-19 and practice related to prevention of COVID-19 transmission. Present study included 720 nursing personals. Majority of study participants were between the age group of 21-30 years and were females. About $42 \%$ of study participants were student nurses. More than $40 \%$ of nurses had experience between 15 years. Health education programs aimed at improving COVID-19 knowledge are necessary to present positive attitudes and maintain appropriate practices. Due to the limited studies till date more studies are needed based on populations of a low socioeconomic status (Zhong et al., 2020).

About 262 (36.4\%) participants of this study showed excellent knowledge regarding myths and facts about COVID-19 with mean score of 12.51 ( $\mathrm{S} . \mathrm{D} \pm 3.88$ ) whereas in rest two areas i.e, COVID-19; causes and clinical manifestations and diagnosis of COVID-19 score were average among about half of participants. In the study predominantly participants had overall good knowledge with mean score 26.19 (S.D \pm 7.33 ) and excellent practice related to prevention of COVID-19 transmission with mean scores 12.43 (S.D \pm 2.37 ). Results of current study indicate that the participants were knowledgeable about COVID-19 and had excellent practices. Similar results were reported by a study conducted by Zhang et al. (2020) on health care workers at Henan, China, in which health care workers demonstrated sufficient knowledge of COVID-19 and were following correct practices regarding COVID-19. In the present study, statistically significant association of knowledge and practice scores with age, gender and education was found ( $p$ value $<0.05)$.

The strength of the study is the sample depicting good knowledge and practices at early stage of the COVID - 19 outbreaks. Also, this study was one of the first studies conducted on Indian nurses during early period of COVID-19 outbreak. Though the sample recruited, was over representative of female participants and included working, unemployed as well as student nurses. Further research must be conducted to compare the knowledge, attitude and practices among different population.

\section{CONCLUSION}

The finding of present study suggests that Indian nurses have relatively good knowledge and practices during rapid rise of COVID -19. As the participants were nursing personnel it is suggested that the care of COVID19 patients is in safe hands. Moreover, the frontline nursing fraternity is all set to win the battle against COIVD-19 in near future.

\section{Conflict of Interests}

The authors declare that they have no conflict of interest.

\section{ACKNOWLEDGEMENT}

The authors are thankful to the institutional authority for completion of the work.

\section{REFERENCES}

Adhikari, S., Meng, S., Wu, Y., Mao, Y., Ye, R., Wang, Q., Sun, C., Sylvia, S., Rozelle, S., Raat, H. \& Zhou, H. (2020). Epidemiology, causes, clinical manifestation and diagnosis, prevention and control of coronavirus disease 
(COVID-19) during the early outbreak period: a scoping review. Infectious Diseases of Poverty, 9(1).

Guan, W., Ni, Z., Hu, Y., Liang, W., Ou, C., He, J., Liu, L., Shan, H., Lei, C., Hui, D., Du, B., Li, L., Zeng, G., Yuen, K., Chen, R., Tang, C., Wang, T., Chen, P., Xiang, J., Li, S., Wang, J., Liang, Z., Peng, Y., Wei, L., Liu, Y., Hu, Y., Peng, P., Wang, J., Liu, J., Chen, Z., Li, G., Zheng, Z., Qiu, S., Luo, J., Ye, C., Zhu, S. \& Zhong, N. (2020). Clinical Characteristics of Coronavirus Disease 2019 in China. New England Journal of Medicine, 382(18), pp 1708-1720.

Guo, Y., Cao, Q., Hong, Z., Tan, Y., Chen, S., Jin, H., Tan, K., Wang, D. \& Yan, Y. (2020). The origin, transmission and clinical therapies on coronavirus disease 2019 (COVID-19) outbreak - an update on the status. Military Medical Research, 7(1).

Huang, C., Wang, Y., Li, X., Ren, L., Zhao, J., Hu, Y., Zhang, L., Fan, G., Xu, J., Gu, X., Cheng, Z., Yu, T., Xia, J., Wei, Y., Wu, W., Xie, X., Yin, W., Li, H., Liu, M., Xiao, Y., Gao, H., Guo, L., Xie, J., Wang, G., Jiang, R., Gao, Z., Jin, Q., Wang, J. \& Cao, B. (2020). Clinical features of patients infected with 2019 novel coronavirus in Wuhan, China. The Lancet, 395(10223), pp 497-506.

Li, Q., Guan, X., Wu, P., Wang, X., Zhou, L., Tong, Y., Ren, R., Leung, K., Lau, E., Wong, J., Xing, X., Xiang, N., Wu, Y., Li, C., Chen, Q., Li, D., Liu, T., Zhao, J., Liu, M., Tu, W., Chen, C., Jin, L., Yang, R., Wang, Q., Zhou, S., Wang, R., Liu, H., Luo, Y., Liu, Y., Shao, G., Li, H., Tao, Z., Yang, Y., Deng, Z., Liu, B., Ma, Z., Zhang, Y., Shi, G., Lam, T., Wu, J., Gao, G., Cowling, B., Yang, B., Leung, G. \& Feng, Z. (2020). Early Transmission Dynamics in Wuhan, China, of Novel Coronavirus-Infected Pneumonia. New England Journal of Medicine, 382(13), pp 1199-1207.

Surveillances, V. (2020). The epidemiological characteristics of an outbreak of 2019 novel coronavirus diseases (COVID-19) - China, 2020. China CDC Weekly, 2(8), 113-122.

World Health Organization. (2019). Middle East respiratory syndrome coronavirus (MERS-CoV). Retrieved from: $<$ https://www.who.int/news-room/fact-sheets/detail/middle-east-respiratory-syndrome-coronavirus-(merscov)>

WHO (2020), Coronavirus. [online] Retrieved from: $<$ https://www. who.int/health-topics/coronavirus\#tab=tab_1 $>$

Zhang, M., Zhou, M., Tang, F., Wang, Y., Nie, H., Zhang, L. \& You, G. (2020). Knowledge, attitude, and practice regarding COVID-19 among healthcare wokers in Henan, China. Journal of Hospital Infection, 105(2020), pp 183-187.

Zhong, B., Luo, W., Li, H., Zhang, Q., Liu, X., Li, W. \& Li, Y. (2020). Knowledge, attitudes, and practices towards COVID-19 among Chinese residents during the rapid rise period of the COVID-19 outbreak: a quick online crosssectional survey. International Journal of Biological Sciences, 16(10), pp 1745-1752.

Zhou, P., Yang, X., Wang, X., Hu, B., Zhang, L., Zhang, W., Si, H., Zhu, Y., Li, B., Huang, C., Chen, H., Chen, J., Luo, Y., Guo, H., Jiang, R., Liu, M., Chen, Y., Shen, X., Wang, X., Zheng, X., Zhao, K., Chen, Q., Deng, F., Liu, L., Yan, B., Zhan, F., Wang, Y., Xiao, G. \& Shi, Z., (2020). A pneumonia outbreak associated with a new coronavirus of probable bat origin. Nature, 579(7798), pp 270-273. 